DOI https://doi.org/10.36059/978-966-397-203-9/105-125

\title{
MENTALITY AND CULTURE
}

\section{Uvarova T. I.}

\section{INTRODUCTION}

The last decades of human existence have one clear tendency - the increase of ethnonational activity in many countries of the world. These processes are also connected with Ukrainian culture. The wave of ethnonational activism is not extinguished even in the conditions of intensive implementation of the ideas of the international community and European integration. Therefore, in recent years, the mentality has been the object of scrupulous attention connected with the formation of a new order in society, which is accompanied by significant changes in the way of life and conscience. A great deal of interest in issues relating to mentality became demanded by the life itself. For the first, it is attributable to the fact that the features of the current transitional stage in Ukrainian culture require an in-depth study of the phenomena associated with solving the issue of human self-identification in the era of globalization, and secondly, the national identity of the Ukrainian people continues to evolve. Attitudinal aspects of life that are directly related to mentality are becoming more relevant.

In this case, the science of culture claims the status of a methodological strategy, method, and toolkit for explaining global transformations and is required to maintain the sustainable development of civilization as never before.

The category of mentality in cultural studies is still unexplored. A number of methodological and theoretical issues remain unresolved. Not only the introduction of the term "mentality" into scientific circulation is problematic, but there is also a terminological inconsistency in the definition of this term by scholars. This can be explained by the fact that mentality is a complex, multi-layered and integrative phenomenon of one`s spiritual existence. Therefore, by using an interdisciplinary and cultural method of research, we aim to trace the history of the emergence and introduction of this term into scientific circulation, to consider the study of the category of mentality as a complex, multi-level cultural phenomenon, to highlight the connection 
between mentality and culture, to find out the components of culture forming parameters of Ukrainian mentality.

\section{History of the formation of "mentality" category}

First of all, it should be noted that the category "mentality" derives from the term "mentalis", which appeared in the fourteenth century and denoted mind, reason and intelligence affiliation in medieval scholasticism. In science, the emergence of the term came gradually from spoken language. It began to be used in ethnology, psychology, anthropology.

"Mentality" was introduced into the scientific usage by the American philosopher R. Emerson in the $1840 \mathrm{~s}-1850 \mathrm{~s}$. His interpretation of this concept had, first and foremost, a mystical meaning and had little to do with its subsequent use in philosophical and cultural literature. This is probably why it has not been used in science for quite some time.

Further development of this direction owes to the work of German scientists H. Steinthal and W. Wundt, who published the book "Lectures on the Soul of Men and Animals", which is based on Hegel's ideas about "objective spirit"; to the widespread notions of "supra-individual psyche" and "popular spirit" in Germany at that time"; and also to the representative of the historical school of law, the German geographer and the historian K. Richter, who pointed out the conditionality of history on the people's spirituality in his writings ${ }^{2}$.

In 1860, M. Latsarus and H. Steinthal characterized the "folk spirit" as a special, closed entity that manifests itself in the psychology of the similarities of individuals belonging to a particular nation, as well as features of their consciousness, the content of which can be revealed by comparative language, mythology, morality and culture studies. At the beginning of the XX century, these ideas were developed and partially implemented in W. Wundt's "The Psychology of Nations" by ${ }^{3}$.

The scientific development of the term "mentality" and its introduction into widespread use is considered an achievement of the representatives of the French historical school "Annales" (M. Bloch, J. Le Feuvre, J. Le Goff, M. Proust, G. Duby). French scientists and their

1 Брокгауз Ф.А. Энциклопедический словарь. Философия и литература. Мифология и религия. Язык и культура, Москва, 2003. 405

2 Брокгауз Ф.А. Энциклопедический словарь. Философия и литература. Мифология и религия. Язык и культура, Москва, 2003. 555

${ }^{3}$ Вундт В. Психология народов: Сборник, Москва, 2002. 119 
followers have developed the category of "mentality" within anthropological research and in many ways contributed to its acquisition of the general scientific status.

In the $1920 \mathrm{~s}$, the notion of "mentality" was actively explored, first of all in France, in particular by M. Proust (the third volume "Hermant" of the epic "In Search of the Lost Time", 1921). In 1922, the representatives of the historical psychology and cultural anthropology resorted to the analysis of two types of mentality - paralogical and logical, in particular in L. Lévy-Bruhl's monograph "Primitive mentality".

The works of L. Febvre (the `30s) became prominent in the study of mentality issues, which distinguishes the concept of collective and individual mentality as specific constants of human thinking, determined by the biological laws.

The systematic development of mentality issues began solely in the 1940 s ("Anthology of History, or The Historian's Craft" by M. Bloch and "The Problem of Unbelief in the Sixteenth Century. The Religion of Rabelais "by L. Febvre). Mentality appears as a kind of correlation of ideology and utopia, as a way of mass-scale individual historical thinking, a vision of history, a particular historical form of the "collective unconscious".

The "mentality" category shows great research potential in the works of representatives of the social sciences and humanities. In the studies of Lévy-Bruhl and K. Lévi-Strauss, the mentality is regarded as a collective consciousness. C.G. Jung, J. Campbell, K. Kerényi, E. Neumann, $\mathrm{M}$. Heidegger considered the issue of the relation of mentality and extrarational. M. Foucault considered the mentality to determine the experience and behavior of the individual. Freud insisted that the individual's own life did not explain his forms of mentality. Thus, this term has been widely used in humanistic knowledge, because it has integrated the new ideas introduced by human science.

\section{Study on Ukrainian mentality}

Considerable attention to the study of mentality is also paid by Ukrainian scientists. Back in the XIX century, active social processes attracted the attention of social philosophical thought in Ukraine. The concept of national character became one of the most relevant issues of the time. Methodological, ideological bases of Ukrainian mentality research are revealed in the works of V. Vernadsky, B. Grinchenko, M. Hrushevsky, M. Drahomanov, D. Dontsov, O. Dukhnovych, 
M. Kostomarov, P. Kulish, V. Lipinski, G. Skovoroda, T. Shevchenko, I. Franko.

Mentality as a factor of revival and formation of national consciousness of the Ukrainian people was considered by V. Shinkaruk, V. Kasyan, M. Popovich, V. Gorsky, A. Bychko, I. Bychko, I. Starovojtova, O. Kirichuk, V. Moskalets; linguistic and cultural aspects of the concept of mentality - by I. Bratko-Kutinsky, O. Kolisnyk, L. Yasnitsky; the influence of mentality on the everyday basis of the nation - E. Bystritsky, V. Proleev, V. Ivanov; psychological basis of the existence of mentality - V. Yaniv, O. Kirichuk, O. Kulchitsky, M. Shlemkevich; the issue of mentality modeling was considered by Yu. Kanigin.

The achievements of these and many other scientists, whose scientific interest is the issue of mentality, shed light on important aspects of this contradictory and complex phenomenon. But we can say that there are many definitions of mentality among Ukrainian scholars that are not always consistent with one another. Analysis of the literature showed that the concept of "mentality" is associated with "national character", which is sometimes called "mindset of the nation", "national consciousness", "soul of the people", "national temperament", "national wisdom", "Ukrainian national features", "ethnic self-consciousness" and so forth. But in our view, it should be distinguished between these concepts and the mentality.

Concerning the relation of national character and mentality, it should be noted that already in the nineteenth century, the concept of national character became perhaps the most relevant issue of socio-philosophical thought, chiefly as a result of the active national processes that took place at that time. The philosophy of the Ukrainian national idea began to develop, which was connected with the analysis of the specifics of the Ukrainian life-world and culture as factors of the formation of peculiarities of the Ukrainian national character. From activities of the Cyril and Methodius Brotherhood, (M.Kostomarov) onwards, the concept of Ukrainian national character has received the status of a scientific, ideological issue. At the same time, the development of the methodological, ideological basis of the Ukrainian mentality research begins.

The identification of mentality with the national character is one of the most common topics in the scientific literature. The scientist 
A.P. Sadokhin believes that the national character is not inherited from ancestors, but acquired in the process of education ${ }^{4}$, that is, the author does not assume any mechanisms of preserving and transmitting of culture. N.V. Nebylitsa: "In contrast to the national character, the mentality goes back to the very foundations of social life. The mentality is by no means identical with the national character since it includes selfawareness, self-identification, the perception of the past and future of the social environment where one lives, as well as social orientations, habits, traditions, professional activity" .

The national character is "the specific, historically formed system integrity of the persistent diverse properties and characteristics typical for a particular national community that provides it with the qualitative definition that enables to distinguish between the psychology and nations" ". Today, scientists primarily define national character as "the set of socio-psychological traits or constants inherent to a particular nation at a certain stage of its development",

Modern research has shown that the phenomenon of a national character spans different levels of social reality. It is manifested not only in the activities of various social agents, ranging from large social groups (nation) to an individual representing this nation, but also in dominant social attitude, systems of moral requirements, social norms, guidelines, basic values, forms socialization, principles of education, in the nature of human interaction and environmental influences, in the originality of the group's picture of the world, forms of organization of life, relaxation, recreation, etc. I. Fedorchenko writes that "traits of a national character are most clearly manifested in cases where their representatives are not individuals, but groups and communities" ${ }^{\prime 8}$. But, as distinct from the national character, it is important to understand that mentality is a worldview matrix, a picture of the world in a person's mind and its

${ }^{4}$ Садохин А. П. Этнология, 2002. 144.

5 Небилиця Н. В. Менталітет як світоглядна та теоретична проблема. Культура народів Причорномор'я, Сімферополь, 2004. 127

${ }^{6}$ Федорченко I. Становлення національного характеру українського народу: теоретико-методологічні засади. Вісник Київського національного університету імені Тараса Шевченка. Серія: Украӥнознавство Випуск 11, Київ, 2007. 18

7 Гримич М. Два виміри національного характеру. Наука $і$ суспільство. 1991. № 8.15

${ }^{8}$ Федорченко I. Становлення національного характеру українського народу, Київ, 2007. 18 
involvement in this picture. This is the norm of representing the human environment and humans` place in it.

I. Gabdulgafarov studied the relation between mentality and national character. It concluded that "the national community is characterized by some unique worldview, thinking, way of behavior, value system, spiritual creativity, caused by many factors, and it would be wrong to single out any of these features as a primary, priority. And this whole set of features that distinguishes one ethnocultural community among others, which puts it into a peculiar macrocosm of human individuals, some unique community, can be expressed and most fully characterized by the concept of mentality" ${ }^{\prime 9}$. Therefore, national character is the most important component of the mentality of the nation, the core of its psychology.

Identifying the "national character" with the "mindset of the nation" is also not accurate, since the national character is only a component of the mindset of the nation, and the mindset of the nation includes not only the national character but also the national consciousness and selfconsciousness, national feelings, national traditions, customs and so forth. This was clarified in the early $1980 \mathrm{~s}$ during a rather meaningful discussion on national issues. S. Arutyunov, Y. Bromley, V. Kozlov, I. Kon, L. Drobizheva and other well-known scientists supported A. Dashdamirov's position regarding the categorical separation of the concepts of "national character" and "mindset the nation". In the understanding of these scholars, national character is a more stable component and basis of the nation's mindset.

Scientists propose to consider "mentality" as the common psychological equipment of representatives of a particular culture, which allows the chaotic flow of various impressions to integrate consciousness into a certain worldview. It determines, after all, the behavior of a person, a social group, a society, which results in the "subjective crosssection" of social dynamics being organically incorporated into an objective historical process.

In the $1920 \mathrm{~s}$, prominent Ukrainian sociologist V. Starosolsky introduced the concept of "ethnic identity" ("Theory of the Nation", 1922). I. Grabovskaya reminds a short history of terminological concepts

${ }^{9}$ Габдулгафарова И.М. Национальный характер. О проблеме национального характера и менталитета URL: http://www.region. - orenburg. ru / Sosios (dama звернення: 08.11.2019). 
development: "The notion of "national or people's character" is a definite analog of the concept of "mentality" in the Ukrainian tradition, which has been established in diaspora historical-philosophical schools quite long ago. Today, many Ukrainian researchers are in favor of such a widespread interpretation of the term "mentality". "The national character, or "character of the people", as defined by the professor of the Ukrainian Institute of Social Studies in Prague N. Gregoryiv in the special issue "Ukrainian National Character" is the common thing that "everyone has, which unites them into one human type, and in relation to other peoples, to all mankind - is the thing that distinguishes peoples from one another" ${ }^{\prime 10}$.

The concept of "mentality" is also associated with the concept of "folk wisdom". E. Makarenko writes that "in folk wisdom, as well as in mentality, everything is interdependent: aesthetic and moral regulations, philosophical" insight "and practical skills that are also united and can be separated only for analytical purposes"11.

For the characterization of a people, along with the term "mentality", the concept of "national temperament" is used. Some authors consider the term "national temperament" as unscientific. Thus, in 1983, the scientist O. Leontiev questioned the expediency of using "such a quasiscientific category, considering that such a concept is most likely a metaphor"," as well as the concept of "national needs". After all, the type of temperament is related to the properties of higher nervous activity and the type of human nervous system (therefore these signs may not be characteristics of the community).

In addition to the concept of "Ukrainian mentality", the concepts of "Ukrainian national consciousness" and "national self-consciousness" are used. Consciousness, in general, is the understanding or, more precisely, the awareness of one as a subject of his own actions, needs, interests, feelings, thoughts, motives of behavior and ideals, his position in the natural and social environment. The national consciousness indicates the commonality of national origin, the common belonging to the native land, the unwavering interest in relation to the historical past

${ }^{10}$ Грабовська I. Проблеми засад дослідження українського менталітету та національного характеру. Сучасність. 1998. No 5.59

11 Макаренко Е.М. Ментальність і формування політичної культури нації (соціально-філософський аналіз), Київ, 2000. 6

12 Леонтьев А. А. Национальная психология и этнопсихология. Советская этнография, Москва, 1983. № 2. 81 
and present. National consciousness is the set of traits of an individual, group or community that emerged in the process of communicating with representatives of other national communities. Researcher I. Kresina identifies three levels of national consciousness: everyday, theoretical, state-political, and covers various manifestations of biogeofactors at all levels of national consciousness. "The everyday level is characterized by the unity of conscious and unconscious, mental and archetypal elements of national consciousness: established, relatively stable customs, mental priorities, and attitudes, features, stereotypes, fixed by a long intergenerational tradition, as well as dynamic and transient needs, dynamic and transient values. The theoretical level of national consciousness is scientifically grounded or artificially conceived ideas, concepts, programs, worldviews that characterize the intellectual potential of a nation, it's capacity on the basis of reflection to selfmastery and self-affirmation. It is at the theoretical level where the national idea and ideal, are formed and substantiated. Finally, the statepolitical level is the level of national consciousness at which national interests, political demands, state policy are directly fixed and formed"13. Therefore, the term "national self-consciousness" should be understood as a whole set of ideas of the nation about itself (including the awareness of its representatives about their own identity to it), its conscious interests, values, orientations, and attitudes towards other nationalities.

The emotional side of national self-consciousness is a national feeling. In the national self-consciousness, the idea of the historical destiny of its people, its traditions is very important. National consciousness, including national feelings, always imbued with historicism-national ideas and feelings of new generations are formed both on the basis of direct impressions and experiences of each person, and (it is often decisive) as a result of the development of already existing national ideas and national psychology of the whole nation. The structure of national self-consciousness includes views and ideas related to the self-determination of the national community, with the awareness of social, socio-political, moral, aesthetic and many other values, including psychic mindset, national character, norms, preferences. Due to self-consciousness, the nation gains the capacity for self-protection, self-development.

${ }^{13}$ Кресіна І. Українська національна свідомість і сучасні політичні процеси (Етнополітологічний аналіз), Київ, 1998. 57 
Therefore, the concepts of "national character", "mindset of the nation", "national consciousness", "soul of the people", "national temperament", "folks wisdom", "Ukrainian national character", "ethnic self-consciousness" and others are close and interrelated. Of course, they are important for the understanding of the mentality but are not identical to it.

\section{The category "mentality" in research practices}

Despite a number of thorough studies, there is a methodological and terminological difficulty in research of mentality. Analysis of the works of foreign and domestic scientists makes it possible to distinguish between the study approaches in this category.

The definition of mentality can be divided into several types. In his article "The issue of defining the concept of "mentality"14, R. Dodonov says that there are six types of definitions. The first one is descriptive definitions. In this group of definitions, the focus is on the enumeration of everything included in the mentality (mentality is a set of representations, ways of behavior and reactions, unconscious and unreflected (G. Tellenbach)). The second type is psychological definitions. They, for their part, are divided into two types. The first group focuses on the unconscious level of the psyche (the concept of "mentality" means a certain set of unconscious forms of worldview that have already developed and are specific to a certain group of people, and determine common traits, attitudes, and behavior of these people in relation to the phenomena of their existence (V. Nesterenko). Psychological definitions reflect the idea that mentality is a manifestation of the conscious level of the psyche (mentality is a generalization of all characteristics of the mind (J. Chaplin); mentality is the feature of the mind, which characterizes one individual or class of individuals (most English-speaking psychologists). The third type is the normative definitions that define the mentality as the reaction norms specific for a particular social or ethnic formation (mentality is a concept that defines the system of habits of consciousness (A. J. Toynbee). The fourth type, structural definitions, focuses on the structure of mental processes (mentality is filling quantitative explanation of reality structure with deep sense (F. Sellin); mentality is the structure, composition of the human

14 Додонов Р.А. К проблеме определения понятия “ментальность”. Придніпровський науковий вісник. 1999. № 14 (25). 11-15 
soul, society, ethnicity, the ratio of its elements and the state of the latter (Yu. Kanygin, M. Kholodna); the last two types of definitions of the mentality are genetic and historical. Genetic definitions focus on the origin of this phenomenon. Researchers list the factors that determine the process of emergence and further development of ethnic mentality and note that innate and social factors are transmitted genetically providing mental continuity (mentality is an ethnic and cognitive code (E. Shulin)). Historical definitions refer to mentality as a manifestation of historical memory (mentality is a kind of memory of the people`s past, a psychological determinant of the behavior of millions of people under all circumstances true to their code, which has evolved historically (I. Pantin)).

The search for the reflection of the specific existence of the nation can be traced in the definitions of linguists. They carry out the research on the main factors of linguistic mentality ${ }^{15,16,17}$. In their works, they adhere to the fact that, on the one hand, the language of the people, their worldviews affect the language, each people explicates the peculiarities of its worldview into the linguistic formulas, on the other hand language always embodies the identity of a whole people.

This is close to the standpoint of psychologists' concept of mentality as a national character, psychological type of community, national psycho-cultural phenomenon. The specificity of the psychological approach, according to the researcher's definition, is "first, the disclosure of mentality as a characteristic of individual consciousness, second, the reflection of the surrounding reality by the individual as the main way of mental manifestation, and third, emphasizing the role of culture in this environment as the main factor that shapes the mentality. Researcherspsychologists are proposed to add the concept of "subject" to the concept of "mentality". "The indefinite term" mentality "is practically understood

15 Макаренко Е.М. Ментальність і формування політичної культури нації (соціально-філософський аналіз), Київ, 2000.

16 Додонов Р.А. К проблеме определения понятия “ментальность”. Придніпровський науковий вісник. 1999. № 14 (25).

17 Федорченко I. Становлення національного характеру українського народу: теоретико-методологічні засади. Вісник Київського національного університету імені Тараса Шевченка. Серія: Украӥнознавство Випуск 11, Київ, 2007. 
as" the mentality of the subject's activity" 18 . The idea of a subjectactivity approach to the issue of mentality, according to T. Ivanova, consists in the level of "subjectivity", which determines the level of generalization at which the term "mentality" is used". That is, each level has its own specificity, additional names, and characteristics of the level. For example, if the subject is understood as humanity in general, the mentality of humanity is civilization. If the subject is a people, the mentality of the people is culture. Consideration of the nation as a group subject is defined as the character of the nation. If the subject is a country, it is a mentality of the country, which is characterized by public consciousness. Such a scheme can be regarded as a classification of mentalities.

The anthropological approach proposes to consider mentality as a system of relatively stable stereotypes that reflect the statistical features of the social type formed in the process of human behavior establishment. The peculiarity of this interpretation is that the mentality is has a function of an interpretative model, which expresses one of the sides of social communities' existence ${ }^{20}$.

The philosophical understanding of mentality as a natural and social phenomenon implies that all branches of social science appeal to this process. The peculiarity of philosophical understanding of mentality has two positions: in terms of ontology - as a real phenomenon that objectively exists, and in terms of epistemology - as a theoretical construct, a tool of the researcher, modeled with the purpose of clarification of social complex ${ }^{21}$.

There is also a cultural approach to the interpretation of mentality. If the psychological approach emphasizes the psychological features of thinking, the perception of the world at the level of ethnicity, class or any other social community (also professional), then the cultural one, while ignoring the psychological component, pays more attention to national, historical and cultural traditions. The cultural approach views mentality

${ }^{18}$ Иванова Т.В. Ментальность, культура, искусство. Общественные науки и современность. 2002. № 6.168

19 Иванова Т.В. Ментальность, культура, искусство. Общественные науки и современность. 2002. № 6. 168-170

20 Небилиця Н. В. Менталітет як світоглядна та теоретична проблема. Культура народів Причерноморья, Сімферополь, 2004. 126

21 Небилиця Н. В. Менталітет як світоглядна та теоретична проблема. Культура народів Причорномор'я, Сімферополь, 2004. 126 
as some integral characteristic of people living in a particular culture. This characteristic allows us to describe the originality of the vision of the world by these people and to explain the specifics of their reaction to it. That is, the cultural interpretation of the mentality is based on the position of the person as part of the culture. Hence the mentality is a set of ways of production of society, its interaction with nature, activities of social institutions and other regulators of social life, as well as beliefs, the hierarchy of values, morality, peculiarities of interpersonal behavior and expression, language, a way of passing experience on through generations.

All these types of definitions complement each other in some way but do not fully embrace the complex mentality phenomenon. Very often they ignore such objective characteristics as geo-environment, economic, social, political factors of social development.

Therefore, in the analyzed scientific works, there is a considerable number of definitions of the term, in which there are disciplinary features of the formulated definitions, that is, attempts to give a definition of mentality are interdisciplinary. Contrary to the quest for universality, the accents make it possible to characterize the specific vision of the object under study by the representatives of each direction.

\section{4. "Mentality" as the category of culture}

The issue of mentality as a category of culture causes a great deal of interest among domestic and foreign professionals. Under mentality, they understand the cultural and psychological phenomenon; psycho-cultural image of the nation, direct-procedural layer of national culture; psychological inheritance that determines behavior and experience (O. Donchenko); "Thinking tools" of a human being and society; joint psychological equipping of representatives of a particular culture, enabling to integrate the chaotic flow of various impressions into a certain worldview with consciousness; the level of social consciousness, at which thought is integral to emotions, latent habits and techniques of consciousness (A. Gurevich); the collective unconscious; the social character and individuality of the ethnic group (nation); sociopsychological self-organization of representatives of a certain cultural tradition (A. Ruban). They also believe that mentality is connected with spirituality, culture, and existence (substantive reality), and therefore determines the deep sense of human actions, historical events, and epics 
(V. Znakov); mentality is a sensory-thinking toolkit for environmental development that determines human behavior (Starovoitov).

Gurevich also researched the mentality in culture ${ }^{22}$. From his point of view, mentality appears as one of the layers of social integrity. Mentality features such as the perception of time, space, relation to the nature of the extraordinary, labor morality, relation to wealth and poverty, rights, emotions - are expressions of the human personality. Without their interpretation, one cannot approach the issue of mentality. The scientist is not referring to a set of values, but rather to an understanding of mentality as a phenomenon of culture. He understands mentality as a category of culture as a relatively stable characteristic of the consciousunconscious worldview and behavior, due to the deep national historical and cultural traditions ${ }^{23}$.

In his fundamental work "The History of Mentality in Europe. Essays on major topics" edited by P. Dintzelbacher the list of the big topics that should be addressed by the mentality involves: individual, family and society, sexuality and love, religiosity, body and soul, illness, age, death, fears and hopes, joy, sadness and happiness, work and holiday, communication, others` and their own possessions, power, rights, nature and environment, space, time and history ${ }^{24}$. According to P. Dintzelbacher, the mentality is a "combination of the ways and meanings of thinking and perception that define the particular group. Mentality manifests itself in action, its history is more than a study of the intellectual conditioning of the elites or individual figures and thinkers, it is more than a history of religion and ideology, it is more than a history of emotions and ideas, because all of the above is a kind of ancillary disciplines for the study of mentality. Only when the results obtained within these disciplines give a unique combination of characteristic interrelated elements, we can say that a certain mentality is mentioned"25.

${ }^{22}$ Гуревич П.С. Культурология, Москва, 2002.

${ }^{23}$ Гуревич П.С. Культурология, Москва, 2002. 239.

${ }^{24}$ Динцельбахер И. История ментальности в Европе. Очерки по основным темам. История ментальностей. Историческая антропология, Москва, 1996.

${ }^{25}$ Динцельбахер И. История ментальности в Европе. Очерки по основным темам. История ментальностей. Историческая антропология, Москва, 1996. 97-98. 
Mentality as an integrative characteristic of culture is covered in the work of Getalo $\mathrm{T}^{26}$. The author believes that mentality always implies socio-cultural content, so his typology is determined by the typology of the cultural and historical processes ${ }^{27}$.

The concepts of "mentality" and "culture" were compared by scientist T. Ivanova ${ }^{28}$. The author concludes that mentality is a temporary agreement and the inevitability of existence in a common society. The mentality is related to art through the concept of culture. "Art, according to T. Ivanova, is a part of the culture, and culture is the main and best phenomenon developed in the mentality" ${ }^{29}$. The author also analyzes the relations between art and mentality. Art can be called "specific mentality and it organically enters into the mentality of any level of generalization" ${ }^{30}$.

The issue of mentality as a cultural category prompts us to consider the main directions in the definition of this term. The cultural concept is based on the concept of cultural archetypes (K. Jung), "cultural-historical theory" (L. Vygotsky), "symbolic interactionism" (J. Cooley), and on ideas of M. Barga about culture as a value-symbolic system and spiritual intention to vital activity, who believes that mentality is a compilation of symbols that must be formed within each particular cultural and historical era.

In domestic cultural studies, the mentality is usually used to denote the national characteristics of peoples, the features of culture. The mentality is also understood as deep structures of culture, historically and socially rooted in the minds and behaviors of many generations of people that combine different historical epochs in the development of national culture.

The cultural approach to the interpretation of this concept is focused on national, historical and cultural traditions. Within the scope of cultural

26 Гетало Т.Є. Онтологія ментальності: філософсько-культурололгічний аналіз, Харків, 1999.

27 Гетало Т.Є. Онтологія ментальності: філософсько-культурололгічний аналіз, Харків, 1999. 4

${ }^{28}$ Иванова Т.В. Ментальность, культура, искусство. Общественные науки и современность. 2002. № 6 .

${ }^{29}$ Иванова Т.В. Ментальность, культура, искусство. Общественные науки и современность. 2002. № 6. 170.

${ }^{30}$ Иванова Т.В. Ментальность, культура, искусство. Общественные науки и современность. 2002. № 6. 175. 
interpretation, it is customary to distinguish historical types of mentality (ancient, medieval, Islamic, etc.), ethnonational (Slavic, Scandinavian, Latin-American, and others).

The cultural approach interprets mentality as an integral characteristic of people living in a particular culture. This characteristic allows to describe the originality of their vision of the world and to explain the specifics of their reaction to it. That is, the cultural interpretation of the mentality is based on the idea of a person as part of the culture. Hence the mentality is a set of ways of production of society, its interaction with nature, activities of social institutions and other regulators of social life, as well as beliefs, the hierarchy of values, morality, features of interpersonal behavior and expression, or language, a way of passing on experience through generations. Thus, the cultural aspect of the theory of mentality is to research the ways and methods of studying the social and civilizational structures of the historical process as a whole.

Therefore, the concept of "mentality" is much broader than the concept of "culture". Mentality incorporates culture as the most valuable thing, which becomes the purpose of society's existence and development. Culture is the highest level of development of mentality. The concept of "culture" is individualized in the sense that the culture of the people consists of the cultural traditions and culture of each person. Mentality changes much faster than culture. Culture is more inertial, fundamental. Mentality and culture are close concepts, but qualitatively different categories.

The mentality is not only logical constructs but it also organically includes ethnic, national, cultural, image-emotional components. Mentality involves a certain level of fostering the culture, as well as a sense of historical and religious affiliation and distance from something and from someone. That is why the mentality grows as a complex combination of such components as ethnos, culture, religion, science, morality, art and cannot be reduced to any of them, that is, it always has an integrative and holistic character. The synthesis of all these components is usually done at the subconscious level.

As already mentioned, the mentality is a multifaceted phenomenon of culture. In order to master the issue, it is necessary to consider the important aspects of mentality as a cultural category. This is, first and foremost, the connection of mentality with ideology. In the scientific research there is a separation of the outlook of different social groups the first one consists of clearly understood and declared perceptions and norms, the second is formed by poorly understood or unconscious (or at 
least not formulated) perceptions and norms; the first component was called "ideology", the second was called "mentality",31. Scientist J. Kohan believes that mentality should be viewed in tandem with ideology. The distinction between mentality and ideology, in his understanding, "is based on the identification of patterns in worldviews and behavior of a sufficiently large number of people - who form communities of people, whose mentality may be of great interest to the researcher"32. Fr. Grous says that in general, it's hard to distinguish between culture or ideology in the concept of "mentality". From his point of view, the mentality is "the general tone of long-term behaviors and attitudes of individuals within groups. The mentality can not be monolithic, it is very often contradictory and creates specific patterns of use, stereotypes of thoughts and actions, it manifests itself in the inclination of the individual to certain types of reactions and is their mechanism, 33 . The mentality is different from the doctrines, ideologies because it can never be reflexed and formulated. "The question 'What is your mentality?' makes no sense. The mentality is not identical to the thoughts and actions expressed, it changes over time, and different opinions and patterns of behavior do not have the same vitality.

Another important aspect of understanding the mentality is that this phenomenon is inextricably linked to a particular community. Provided that, first, the members of this community have a certain commonality in their worldviews and, second, in their behavior, patterns related to the commonality of their worldviews can be identified. "Mass phenomena are characterized by mass (aggregate) patterns that arise on the set of local varieties of patterns that characterize the behavior or the inner world of individual"34. For the issue of mentality, this means that only by describing the outlook and behavior of a single individual one can conclude about the mentality of the community.

The phenomenon of mentality is directly connected with the human being, and in the most general sense, it is commonly defined as features

31 Левинсон К. А. Ментальности и средневековье. Концепции и практика. История ментальностей. Историческая антропология, Москва, 1996. 110

${ }^{32}$ Левинсон К. А. Ментальности и средневековье. Концепции и практика. История ментальностей. Историческая антропология, Москва, 1996. 110

33 Стадник I. Б. Українська ментальність у контексті відродження національної духовності, Одеса, 2003.

34 Левинсон К. А. Ментальности и средневековье. Концепции и практика. История ментальностей. Историческая антропология, Москва, 1996. 111 
of thoughts, mindset, mind that characterize a certain socio-cultural community on a scale of a certain era. But the main point is that the basis of this phenomenon is the basic relation of a human being and culture. In this context, the mentality is a category that defines the contemporary context of a human ontology in culture, human's worldview through the prism of one's own ethnic group (nation) or social community.

The mentality is a worldview matrix, a picture of the world in the mind of a human being and human's involvement in this picture. This is the norm of representing the human's environment and human in it. Hence the mentality is a compilation of ways of production of society, its interaction with nature, activities of social institutions and other regulators of social life, as well as beliefs, the hierarchy of values, morality, features of interpersonal behavior and expression, or language, a way of passing on experience through generations.

Culture defines different types of status descriptions. In this case, the bearer of a particular ethnic culture creates numerous variants of understanding the environment, which depends on specific situations, environment, status, demographic and other positions. Therefore, the study of mentality is also linked to the study of ethnic cultures. In this case, the orientation of the mentality of each person and, accordingly, his ethnic culture, will correspond to the type of mentality that is most evident in the religious and philosophical doctrines that create a certain type of general mentality of his ethnic culture.

Culture, and therefore mentality, are associated with archetypes. The culture of the people has its roots in the invisible peculiarity of the mentality, the core of which are particularly important key archetypes. Therefore, mentality as a complex invariant system includes archetypes. The nature of the archetypes is stable, they are not often affected by collisions. Therefore, the mentality is quite stable.

Each culture (mentality) can be identified with only its own set of archetypes, on the basis of which the cultural identity of a way of life is formed and traditions are preserved. The task of grasping the essence of mentality involves, first of all, the elucidation of the key peculiarity of archetypes. It is the archetypes that give the culture bearers samples of behavior. Due to archetypes, everyone behaves traditionally in standard situations. Archetypes are more subconscious and instinctive phenomena; they provide algorithms for typical behavior. The archetypal motivations of the actions become intuitively visible when there is a need for a manifestation of belonging to traditions - involvement in one's ethnicity. That is, the mentality is a historically reworked archetypal 
concept, through which the perception of the basic aspects of reality: space, time, art, politics, economy, civilization, religion - that is, culture - takes place.

In the methodology of science, the terms "mentality" and "culture" do not have a clear algorithm for interaction. Those who consider mentality as of new knowledge do not fail to mention the culture that emerged such a definition. The researchers of culture as a whole phenomenon include mentality in the composition of culture, integrating new knowledge, into the term "mentality". In any case, the mentality is not limited by culture; it includes the way of thinking, national character, values, mental processes, activities that make it a general term.

But one cannot regard the relation between culture and mentality as one and the whole. Culture is a concept of mentality, and there is a downside - mentality is reflected in culture. "The culture of the historical era is the highest level of development of the mentality of this era, which creates the basis for the emergence of a new culture of a new historical period. The mentality is not a formed culture, but a certain intermediate stage of culture formation. Something socially and historically significant, entrenched in mentality becomes a culture" ${ }^{, 35}$.

As an example of the fact that mentality creates culture, the processes that take place in Ukraine may be evidence. Under the influence of Western propaganda, new mentalities are born: political, economic, and so forth. It is not about changing the culture, although new layers are certainly influencing it. Only time will tell which of the new mentalities will enter the culture of the people.

\section{CONCLUSIONS}

Mentality is a many-sided interdisciplinary concept, and correlation of mentality and culture has not defined yet. On such state of affairs influences also circumstance that there is plenty of determinations of the phenomenon of culture, and consequently problematical character of understanding of the phenomenon of mentality is kept. Such situation exists in any difficult interdisciplinary sphere of research. All this testifies about multidimensionalness and ambiguousness of mentality as categories of culture, that makes impossible unambiguous judgment about it. In addition, such category of culture as "mentality" is new

35 Иванова Т.В. Ментальность, культура, искусство. Общественные науки и современность. 2002. № 6. 173. 
enough. Culturology has not yet fully developed the experience of its thorough and consistent study. Cultural studies are already at the stage of their formation, hence the categorical inappropriateness of this concept.

However a number of problems of the culturological aspect of mentality remain outside the scope of this study. But such problems as: mentality in the cultural life of youth; the destructive influence of postmodern mentality on humanity; mentality as a cultural resource of science; the role of mentality in the life of society; mentality and the formation of the political culture of the nation, etc., we consider promising for further research work. We believe that at the crucial stages of the development of mankind, it is necessary to take into account the concept of mentality. We believe that at the crucial stages of the development of mankind it is necessary to take into account the concept of mentality, since it is not a decisive condition for overcoming the problems of cultural science, nevertheless, it can help to achieve positive results in most of them.

\section{SUMMARY}

The article traces the history of the appearance and use of the term and "mentality. The article considers the category of "mentality" as an object of study in culturology. Cultural science is the methodological basis of this research. It has been found that there is a widespread use of this term in humanitarian knowledge, but the definitions of the term "mentality" in the works of domestic and foreign researchers do not always agree with each other. It is established that the concept of "national character", "mental composition of the nation", "national consciousness", "soul of the people", "national temperament", "folk wisdom", "ukrainian national attitude", "ethnic self-consciousness" and others are close and interconnected. They are important for understanding the mentality, but not identical to it.

Research approaches to defining mentality as a category of culture have been analyzed. It is established that, despite the desire for universality, there is no exhaustive definition of this complex phenomenon. The features of the relationship between mentality and culture are explained in the article. Culture is a concept of mentality, and mentality, in turn, is reflected in culture. Mentality appears as a multifaceted phenomenon of culture - as a worldview matrix of man the carrier of culture. 


\section{REFERENCES}

1. Брокгауз Ф.А. Энциклопедический словарь. Философия и литература. Мифология и религия. Язык и культура, Москва, 2003. 592 c.

2. Вундт В. Психология народов: Сборник, Москва, 2002. 863 с.

3. Габдулгафарова И.М. Национальный характер. О проблеме национального характера и менталитета URL: http://www.region. orenburg. ru / Sosios (дата звернення: 08.11.2019).

4. Гетало Т.Є. Онтологія ментальності: філософськокультурололгічний аналіз, Харків, 1999. 19 с.

5. Грабовська I. Проблеми засад дослідження українського менталітету та національного характеру. Сучасність. 1998. No 5. C. 58-70.

6. Гримич М. Два виміри національного характеру. Наука і суспільство. 1991. № 8. С. 27-31.

7. Гуревич П.С. Культурология, Москва, 2002. 280 с.

8. Динцельбахер И. История ментальности в Европе. Очерки по основным темам. История ментальностей. Историческая антропология, Москва, 1996. 345 с.

9. Додонов Р.А. К проблеме определения понятия “ментальность". Придніпровський науковий вісник. 1999. № 14 (25). C. 10-17.

10. Иванова Т.В. Ментальность, культура, искусство. Общественные науки и современность. 2002. №6. С. 168-177.

11. Кресіна I. Українська національна свідомість і сучасні політичні процеси (Етнополітологічний аналіз), Київ, 1998. 392 с.

12. Левинсон К. А. Ментальности и средневековье. Концепции и практика. История ментальностей. Историческая антропология, Москва, 1996. 345 с.

13. Леонтьев А. А. Национальная психология и етнопсихология. Советская этнография, Москва, 1983. № 2. С. 80-82.

14. Макаренко Е.М. Ментальність і формування політичної культури нації (соціально-філософський аналіз), Київ, 2000. 16 с.

15. Небилиця Н. В. Менталітет як світоглядна та теоретична проблема. Культура народів Причорномор'я, Сімферополь, 2004. C. 125-127.

16. Садохин А. П. Этнология, 2002, 288 с.

17. Стадник І. Б. Українська ментальність у контексті відродження національної духовності, Одеса, 2003. 20 с. 
18. Федорченко I. Становлення національного характеру українського народу: теоретико-методологічні засади. Вісник Київського національного університету імені Тараса Шевченка. Серія: Українознавство Випуск 11, Київ, 2007. С. 17-20.

\section{Information about the author:}

Uvarova T. I., $\mathrm{PhD}$ in Arts, Associate Professor at the Department of arts and humanities studies, International Humanitarian University, 33, Fontanska Road St., Odessa, 65009, Ukraine 